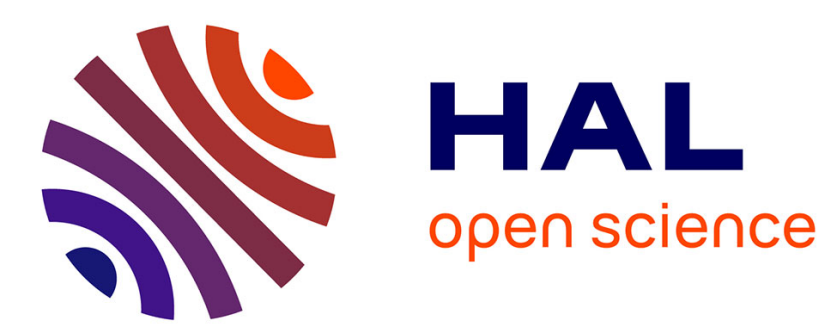

\title{
A survey of on-farm acceptance of low-input measures in intensive agriculture
}

\author{
Juliane Mante, Bärbel Gerowitt
}

\section{To cite this version:}

Juliane Mante, Bärbel Gerowitt. A survey of on-farm acceptance of low-input measures in intensive agriculture. Agronomy for Sustainable Development, 2007, 27 (4), pp.399-406. hal-00886390

\section{HAL Id: hal-00886390 \\ https://hal.science/hal-00886390}

Submitted on 1 Jan 2007

HAL is a multi-disciplinary open access archive for the deposit and dissemination of scientific research documents, whether they are published or not. The documents may come from teaching and research institutions in France or abroad, or from public or private research centers.
L'archive ouverte pluridisciplinaire HAL, est destinée au dépôt et à la diffusion de documents scientifiques de niveau recherche, publiés ou non, émanant des établissements d'enseignement et de recherche français ou étrangers, des laboratoires publics ou privés. 


\title{
A survey of on-farm acceptance of low-input measures in intensive agriculture
}

\author{
Juliane MANTE*, Bärbel GEROWITT \\ University of Rostock, Institute for Land Use, Satower Str. 48, 18051 Rostock, Germany
}

(Accepted 16 August 2007)

\begin{abstract}
Low-input measures is used as a generic term for all measures involving a reduced intensity of agricultural management to enhance the quality of biotic or abiotic goods. Intensive agricultural regions have the lowest share of implemented low-input measures, though they have to resolve the most serious nature conservation and environmental problems. To understand the conditions for a better implementation of these measures in intensive agricultural areas, we carried out a written survey among 865 farmers in intensively-used arable regions. The adoption patterns of arable and grassland measures were compared. The determining factors were analysed by logistic regression. Arable measures, such as mulch seeding, that claim a high share of the arable area often have comparatively slight restrictions and cause windfall gains. However, our results show that their adoption increases the ratio of probability of a subsequent implementation of low-input measures on grasslands by 0.05 . This means that these arable measures can act as starting measures for probably more valuable low-input measures on grasslands. Furthermore, the relation of the farmers with their subsidising institution proved to have an influence in our analysis. With every next best rating the farmers give for their relation with their subsidising institution, the ratio of probability for the adoption of low-input measures on arable land rises by 0.3 . We also detected a strong positive influence of defined contact persons within the subsidising institution on the probability of adopting grassland measures, with a ratio of probability of 4.802 . These findings show that the subsidising institution has in many respects a central influence on the decision process of the farmer to adopt low-input measures. The described determinants reveal new insights usable for improving the off-farm conditions of an increased implementation of low-input measures in intensively-used arable regions.
\end{abstract}

intensively-used arable regions / agri-environmental measures / low-input farming / determining factors / Germany

\section{INTRODUCTION}

\subsection{Intensive arable regions}

Due to their favourable conditions, arable regions in Europe have been intensively cultivated for centuries (Küster, 1999; Milisauskas and Kruk, 1989). Thus, an open land character has been generated and many animal and plant species have specially adapted to its conditions (Bignal and McCracken, 2000). In the second half of the 20th century the rapid modernisation of agriculture resulted in an intensified agricultural use of many European regions and has had severe negative effects on the environment (Bignal and McCracken, 2000; Tilman et al., 2001). Contemporary intensive cultivation through the increasing use of fertiliser and pesticides and the loss of diverse crop rotations and structural elements have led to a dramatic deterioration of the living conditions of many species (Stoate et al., 2001). Due to this development many studies show declines in farmland birds (Chamberlain et al., 2000), invertebrates (Eggleton et al., 2005), mammals (de la Pena et al., 2003) and arable weeds (Sutcliffe and Kay, 2000). In Germany, so-called "Börde-regions" belong to these open landscapes. They are characterised by their fertile soils, developed mainly in North German ground moraine areas in the Central German uplands from glacial deposited loess (Küster, 1999).

*Corresponding author: juliane.mante@uni-rostock.de

\subsection{Low-input measures}

Implemented agri-environmental measures or nature conservation contracts concentrate strongly in extensively-used less favourable areas with high proportions of grassland (Crabtree et al., 1998; Wilson and Hart, 2000). Low-input production methods in general can be distinguished in measures mainly focused on the conservation of biotic resources and those focused on the protection of abiotic resources. Some measures can be found in both categories because they can partly cause the enhancement of biotic as well as abiotic resources. Furthermore, variants of one measure caused by a different design of obligations can focus either on abiotic or on biotic resources (e.g. different types of extensified grassland). In this contribution the term low-input measures is used as a generic term for measures of both categories.

\subsection{Determinants for farmers' acceptance of low-input measures}

Low-input measures on arable land have a comparatively low acceptance rate, especially measures which radically interfere with usual farm management (Pannell et al., 2006; Vanclay, 2004; Walford, 2002). We identified five fields of research for determining the acceptance of low-input measures. 


\subsubsection{Farm structural and farm economic features}

A big farm size (Lambert et al., 2007; Walford, 2002; Wilson and Hart, 2000), a high farm income (Lambert et al., 2007) and full-time farming (Crabtree et al., 1998; Lambert et al., 2007) can positively influence the acceptance and implementation of low-input measures. Furthermore, a high soil quality, a high livestock density (Dupraz et al., 2003), a high share of rented land (Walford, 2002; Wilson and Hart, 2000) and acreage enlargement (Mann, 2005) can be obstacles for the decision-making process.

\subsubsection{Socioeconomic characteristics of the farm manager}

Younger farmers (Mathijs, 2003; Schmitzberger et al., 2005; Toma and Mathijs, 2007; Walford, 2002; Wilson and Hart, 2000) and those with a higher educational level (Davies and Hodge, 2006; Lambert et al., 2007; Llewellyn et al., 2007; Mathijs, 2003; Wilson and Hart, 2000) are more willing to participate in low-input measures.

\subsubsection{Attitudes and personality features of the farm manager}

The environmental attitudes of the farmer proved to be quite influential on the decision-making process (Davies and Hodge, 2006; Dupraz et al., 2003; Toma and Mathijs, 2007; Pannell et al., 2006). Furthermore, Schmitzberger et al. (2005) show the importance of open-mindedness of the farm manager, whereas Pannell et al. (2006) emphasise the negative impact of farmers' risk-aversion on the adoption of low-input measures.

\subsubsection{Design of the low-input measures}

There is agreement that measures compatible with the existing farm organisation have a high acceptance and adoption rate (Walford, 2002; Wilson and Hart, 2000; Pannell et al., 2006). Also favoured are measures which are easy to comply with, technically feasible (Lambert et al., 2007; Pannell et al., 2006) and profitable (Llewellyn et al., 2007; Pannell et al., 2006; Vanclay, 2004). A low risk and a high flexibility of the measure positively influence its uptake, as well as its divisibility into manageable parts (Pannell et al., 2006; Vanclay, 2004).

\subsubsection{Extension strategies}

The information provided and the farmers' knowledge about the measure are crucial in general for the decision process (Llewellyn et al., 2007; Toma and Mathijs, 2007). Concerning the sources and the process of information, it is important to give the information as early as possible (Schenk et al., 2007), preferably via personal contact and one-to-one conversation (Schenk et al., 2007; Vanclay, 2004). The information must be easy to relate to the farming process and everyday life
(Schenk et al., 2007). The farmers' reliance on or confidence in the advising contact person is also crucial for the adoption process (Lambert et al., 2007; Pannell et al., 2006; Pretty and Smith, 2004).

\subsubsection{Social and structural context of the farm}

This research field refers to the social connectivity of the farmer, also subsumable under the term of social capital (Lambert et al., 2007; Mathijs, 2003; Pannell et al., 2006; Pretty and Smith, 2004). The influence of the broader structural and political context is considered as well (e.g. PintoCorreia et al., 2006). Concerning the social context of a farm, wide personal networks have been investigated as promoting the adoption of low-input measures (Mathijs, 2003; Pannell et al., 2006; Pretty and Smith, 2004).

Regarding the described findings, a focus on intensivelyused agricultural regions is missing - this is required to get an insight into promoting and hindering factors for any implementation of low-input measures in these regions with their special agri-environmental conditions. We therefore want to investigate whether the design of low-input measures influences their adoption pattern in intensively-used agricultural regions (i) and whether different low-input measures influence each other in their uptake (ii). Moreover, the field of extension strategies for low-input measures in intensive agricultural regions requires further investigation. Is the relationship of the farmers to their subsidising institutions affecting decisions (iii) and are defined contact persons within these institutions relevant (iv)?

A survey in three German intensively-used arable regions was carried out to test these hypotheses.

\section{MATERIALS AND METHODS}

\subsection{Data}

In winter 2006 a written survey was carried out among farmers in selected rural districts of the German federal states Lower Saxony, Saxony-Anhalt and North Rhine-Westphalia. All farmers residing in these rural districts were addressed with the help of the Chambers of Agriculture (Lower Saxony, North Rhine-Westphalia) and the Board of Agriculture (Saxony-Anhalt). Hence, a total number of 4720 questionnaires was sent, of which 2284 were addressed to farmers in Lower Saxony, 2018 to farmers in North Rhine-Westphalia and, due to the bigger farm structures, a lower number of 418 farmers in Saxony-Anhalt, resulted from this procedure.

\subsection{Regions}

The rural districts were mainly chosen on the basis of their average yield index. The average yield index is a measured value for the potential yield of the soil in Germany. It is calculated from the valuation index of field applied to the Utilised Agricultural Area (UAA) of a farm. It is mainly used for taxation purposes. The valuation index of field is derived from the 
Table I. Subsumed arable and grassland measures of the agri-environmental programmes of the German federal states Lower Saxony, SaxonyAnhalt and North Rhine-Westphalia (2006).

X: main effect; - : no or side effects; $\square$ : ring-fenced measures; $\square$ : offered (also) as not ring-fenced measures.

\begin{tabular}{|c|c|c|c|c|c|c|c|c|}
\hline & \multirow{2}{*}{\multicolumn{2}{|c|}{ 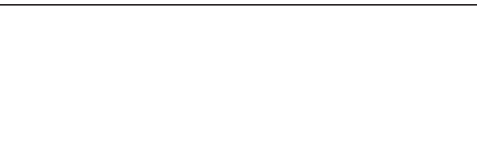 }} & \multicolumn{2}{|c|}{ Lower Saxony } & \multicolumn{2}{|c|}{ Saxony-Anhalt } & \multicolumn{2}{|c|}{$\begin{array}{l}\text { North Rhine- } \\
\text { Westphalia }\end{array}$} \\
\hline & & & Abiotic & Biotic & Abiotic & Biotic & Abiotic & Biotic \\
\hline \multirow[t]{10}{*}{$\begin{array}{l}\text { Arable } \\
\text { land }\end{array}$} & \multicolumn{2}{|c|}{$\begin{array}{l}\text { Restricted pesticide and/ or } \\
\text { fertiliser input }\end{array}$} & $\mathrm{X}$ & - & $\bar{X}$ & - & $\bar{X}$ & - \\
\hline & \multicolumn{2}{|c|}{ Diverse crop rotation } & $X$ & - & $\mathrm{X}$ & $\mathrm{X}$ & $\mathrm{X}$ & - \\
\hline & \multicolumn{2}{|c|}{ Mulch seeding / No-till method } & $X$ & - & $\mathrm{X}$ & - & $\mathrm{X}$ & - \\
\hline & \multicolumn{2}{|c|}{ Organic agriculture } & $\mathrm{X}$ & - & $\mathrm{X}$ & - & $\mathrm{X}$ & - \\
\hline & \multicolumn{2}{|c|}{ Riparian strips } & $\mathrm{X}$ & - & $\mathrm{X}$ & - & $\mathrm{X}$ & - \\
\hline & \multirow[t]{3}{*}{ Field strips } & Seed mixture & $\mathrm{X}$ & $\mathrm{X}$ & & & $\mathrm{X}$ & $X$ \\
\hline & & Succession & & & & & $\mathrm{X}$ & $\mathrm{X}$ \\
\hline & & $\begin{array}{l}\text { Low fertiliser / } \\
\text { pesticide input }\end{array}$ & $X$ & $\mathrm{X}$ & $X$ & $X$ & $\mathrm{X}$ & $\mathrm{X}$ \\
\hline & \multirow[t]{2}{*}{ Set-aside } & Seed mixture & $\mathrm{X}$ & $\mathrm{X}$ & & & $\mathrm{X}$ & $X$ \\
\hline & & Succession & $\mathrm{X}$ & $X$ & & & $X$ & $\mathrm{X}$ \\
\hline \multirow[t]{2}{*}{$\begin{array}{l}\text { Grass- } \\
\text { land }\end{array}$} & \multicolumn{2}{|c|}{$\begin{array}{l}\text { Restricted pasturing, mowing, } \\
\text { management practices, restricted } \\
\text { pesticide / fertiliser input, no } \\
\text { conversion to arable land }\end{array}$} & $\mathrm{X}$ & $\mathrm{X}$ & $\mathrm{X}$ & $\mathrm{X}$ & $\mathrm{X}$ & $\mathrm{X}$ \\
\hline & \multicolumn{2}{|c|}{$\begin{array}{l}\text { Conversion of arable - to grassland } \\
\text { with restricted management }\end{array}$} & $\mathrm{X}$ & $\mathrm{X}$ & $\mathrm{X}$ & $\mathrm{X}$ & $\mathrm{X}$ & $\mathrm{X}$ \\
\hline
\end{tabular}

soil classification of the German valuation frame for the arable land involving climate and relief conditions. The higher the average yield index of the farm or the rural district, the higher the potential yield of its soil. The yield index can amount up to 100 points per hectare.

A second unintended criterion of exclusion was the cooperativeness of the responsible Chambers of Agriculture or Boards of Agriculture, which had to send the prepared questionnaires to the farmers due to data protection reasons. Hence, the following rural districts could be included in the survey: the rural districts Hildesheim and Northeim in the federal state Lower Saxony, and Heinsberg and Viersen in North RhineWestphalia, as well as Weißenfels and Burgenland in SaxonyAnhalt. The average yield indexes of these districts amount to 61-81 per hectare. The agricultural management of these regions is characterised by $80-96 \%$ intensive arable farming with the main crops being winter wheat, winter barley, winter rape and sugar beet.

\subsection{Agri-environmental programmes}

The agri-environmental programmes of the German federal states are individually designed. To obtain subsidies from the European Union and/or the Federal Republic the offered measures must fulfil the minimum requirements according to the responding framework guidelines of the European Union (Regulation (EC) 1257/1999) and the Federal Republic (German Joint Task for the Improvement of Agricultural Structures and Coastal Protection). The federal states can design and cofinance low-input measures with more severe obligations or they can offer measures exclusively financed by themselves.

Table I shows a rough overview of the agri-environmental measures of the federal states Lower Saxony, Saxony-Anhalt and North Rhine-Westphalia at the moment of the written survey. According to their main intended effects - on biotic or abiotic resources - the offered measures are divided into the two categories. One measure in different variants of obligations is subsumed according to its main character (e.g. diverse crop rotation), but can differ in its main intended effects. If different variants of this measure are focused on the protection of different resources (biotic or abiotic), both categories are mentioned. The measures are also characterised by whether they are restricted to certain regions (ring-fenced) or not.

\subsection{Design of the questionnaire}

The questionnaire consisted of five main parts. In the first part the participation in low-input measures on arable land 
Table II. Tested independent variables to explain the adoption or non-adoption of low-input measures on arable land and grassland.

\begin{tabular}{|c|c|c|}
\hline Row number & Variable & Meaning \\
\hline 1 & time & $0=$ part-time farming, $1=$ full-time farming \\
\hline 2 & dairy & Dairy husbandry $(0=$ no; $1=$ yes $)$ \\
\hline 3 & ind & Average valuation index of field (soil quality) \\
\hline 4 & grass & Share of grassland in the UAA of the farm in $\%$ \\
\hline 5 & crop & Share of arable land in the UAA of the farm in $\%$ \\
\hline 6 & UAgrass & Grassland of the farm in hectares \\
\hline 7 & UAcrop & Arable land of the farm in hectares \\
\hline 8 & EMcrop & Share of the arable UAA integrated in low-input measures in $\%$ \\
\hline 9 & EMgrass & Share of the grassland UAA integrated in low-input measures in $\%$ \\
\hline 10 & inc & $\begin{array}{l}\text { Amount of average farm income in } 1000 € \\
(0 \leq 10 ; 1=10-30 ; 2=31-50 ; 3=51-70 ; 4=71-100 ; 5=101-200 ; 6 \geq 200)\end{array}$ \\
\hline 11 & lu & Number of livestock units $(0 \leq 10 ; 1=10-50 ; 2=51-100 ; 3=101-200 ; 4=201-300 ; 5 \geq 00)$ \\
\hline 12 & rent & Share of rented UAA in \% \\
\hline 13 & age & Age of the farm manager $(0=20-40$ years; $1=41-60$ years; $2 \geq 60$ years $)$ \\
\hline 14 & educ & $\begin{array}{l}\text { Agricultural education level } \\
(0=\text { None; } 1 \text { = Basic; } 2=\text { Technician; } 3=\text { University } / \text { Technical College } 4=\mathrm{PhD})\end{array}$ \\
\hline 15 & open & $\begin{array}{l}\text { Low-input measures must not interfere with the usual farm management procedures } \\
\text { (Don't agree at all = } 1 \text { up to Agree absolutely }=5 \text { ) }\end{array}$ \\
\hline 16 & int & $\begin{array}{l}\text { The conservation of biodiversity is an important concern for the farm manager } \\
\text { (Don't agree at all }=1 \text { up to Agree absolutely }=5 \text { ) }\end{array}$ \\
\hline 17 & risk & $\begin{array}{l}\text { Low-input measures are an interesting and important challenge for the farm manager } \\
\text { (Don't agree at all }=1 \text { up to Agree absolutely }=5 \text { ) }\end{array}$ \\
\hline 18 & des & Lower Saxony: Nied (0/1); North Rhine- Westphalia: NRW (0/1); Saxony-A.: SA (0/1) \\
\hline 19 & rel & Relation with subsidising institution $(1=$ very bad up to $6=$ very good $)$ \\
\hline 20 & contact & Defined contact persons in the subsidising institution $(0=$ no; $1=$ yes $)$ \\
\hline
\end{tabular}

and on grassland was enquired. The second section focused on questions that should enable the evaluation of personality features of the farmer. The content of a further section was the ideal design of an extensified field margin programme from the farmers' point of view. The optimal system for farmers to gain subsidies for arable low-input measures and the relation with their subsidising institution were addressed in the fourth part. In the last section farm structural features and socioeconomic characteristics of the farmer were sampled.

\subsection{Analysis of correlations}

To analyse the influencing factors on the adoption of lowinput measures on arable land or grassland, two logistic regressions were carried out. Both dependent non-normal dichotomous variables, implementation of low-input measures on arable land $(0 / 1)$ and on grassland $(0 / 1)$, are the requirements for the appliance of the logistic regression method. The second requirement, the non-existence of multicollinearities between the independent variables, was fulfilled by undertaking a foregoing analysis of correlation and eliminating one variable of a correlative variable pair based on the criterion of the best significance of the model.

The combination of these significant variables that proved the best significance of the model and could explain as much variability of the residual values as possible was identified. The non-significant variables were excluded from the equation. The significance of the model was analysed by the Hosmer and Lemeshow Test (Hosmer and Lemeshow, 2000). The explanation of the variability was estimated by the Nagelkerke $\mathrm{R}^{2}$ (Andreß et al., 1997). Table II shows the analysed independent variables in the following sequence: (a) farm structural and economic features (row 1-12), (b) socioeconomic characteristics of the farmer (row 13-14), (c) farmers' attitudes and personality features (row 15-17), (d) design of the measure (row 18), and (e) extension strategies to promote the measure (row 19-20).

\section{RESULTS AND DISCUSSION}

Overall, the survey's response rate was $20.2 \%$. Lower Saxony had the highest return rate of $26 \%$ responding farmers and Saxony-Anhalt the lowest with $13 \%$ responding farmers. $29.4 \%$ of the farmers in the total sample had implemented lowinput measures at their farms. This share was also highly different between the federal states, with $29.8 \%$ implementing farmers in Lower Saxony, 56.6\% in Saxony-Anhalt and 21.9\% implementing farmers in North Rhine-Westphalia. 
Table III. Summary of the parameter values in the sample (Abbreviations: see Tab. II).

\begin{tabular}{|c|c|c|c|c|c|c|c|c|c|c|c|c|}
\hline \multirow{2}{*}{ Variable } & \multicolumn{4}{|c|}{ Lower Saxony $(\mathrm{n}=590)$} & \multicolumn{4}{|c|}{ Saxony-Anhalt $(\mathrm{n}=53)$} & \multicolumn{4}{|c|}{ North Rhine-Westphalia $(\mathrm{n}=283)$} \\
\hline & Min & Max & Mean & Std. & Min & Max & Mean & Std. & Min & Max & Mean & Std. \\
\hline time & 0 & 1 & 0.63 & 0.48 & 0 & 1 & 0.79 & 0.41 & 0 & 1 & 0.80 & 0.40 \\
\hline dairy & 0 & 1 & 0.19 & 0.39 & 0 & 1 & 0.24 & 0.44 & 0 & 1 & 0.34 & 0.47 \\
\hline ind & 34 & 100 & 71.2 & 13.11 & 45 & 92 & 67.3 & 10.99 & 25 & 92 & 67.4 & 12.88 \\
\hline grass & 0 & 94.0 & 10.0 & 17.12 & 0 & 33.3 & 7.00 & 9.0 & 0 & 97.6 & 12.2 & 14.22 \\
\hline crop & 6 & 100 & 90.0 & 17.35 & 66.7 & 100 & 93.0 & 9.11 & 2.4 & 100 & 87.8 & 14.46 \\
\hline UAgrass & 0 & 145 & 6.11 & 13.34 & 0 & 250 & 25.34 & 49.65 & 0 & 82 & 5.93 & 8.92 \\
\hline UAcrop & 1 & 440 & 71.8 & 68.24 & 1 & 3850 & 491.0 & 880.11 & 1 & 713 & 51.0 & 59.47 \\
\hline EMcrop & 0 & 100 & 8.66 & 22.3 & 0 & 100 & 27.66 & 37.98 & 0 & 100 & 9.89 & 28.32 \\
\hline EMgrass & 0 & 100 & 3.13 & 17.0 & 0 & 100 & 15.29 & 30.72 & 0 & 100 & 5.96 & 22.9 \\
\hline inc & 0 & 5 & 1.34 & 1.31 & 0 & 6 & 2.44 & 2.27 & 0 & 6 & 1.62 & 1.24 \\
\hline lu & 0 & 5 & 1.59 & 0.93 & 0 & 5 & 2.5 & 1.93 & 0 & 5 & 2.16 & 1.21 \\
\hline rent & 0 & 100 & 44.8 & 29.35 & 0 & 100 & 64.4 & 31.45 & 0 & 100 & 60.8 & 30.13 \\
\hline age & 1 & 3 & 1.81 & 0.57 & 1 & 3 & 1.81 & 0.61 & 1 & 3 & 1.77 & 0.56 \\
\hline educ & 0 & 4 & 2.53 & 0.96 & 0 & 4 & 3.22 & 1.07 & 0 & 4 & 2.50 & 0.74 \\
\hline open & 1 & 5 & 3.59 & 1.14 & 1 & 5 & 3.46 & 1.03 & 1 & 5 & 3.92 & 1.17 \\
\hline risk & 1 & 5 & 3.13 & 1.09 & 1 & 5 & 3.00 & 1.09 & 1 & 5 & 2.85 & 1.18 \\
\hline int & 1 & 5 & 3.60 & 1.06 & 1 & 5 & 3.78 & 0.88 & 1 & 5 & 3.67 & 1.01 \\
\hline rel & 1 & 6 & 4.63 & 1.02 & 4 & 6 & 5.03 & 0.74 & 1 & 6 & 4.73 & 1.03 \\
\hline contact & 0 & 1 & 0.45 & 0.49 & 0 & 1 & 0.53 & 0.51 & 0 & 1 & 0.54 & 0.49 \\
\hline
\end{tabular}

\subsection{Parameter values in the sample}

Table III shows the parameter values in the sample. The total sample was divided into three fractions corresponding to the three considered federal states, Lower Saxony, SaxonyAnhalt and North Rhine-Westphalia.

The parameter values indicate some differences between the federal states Lower Saxony, Saxony-Anhalt and North Rhine-Westphalia. Compared with around $80 \%$ of the responding farmers in the other federal states, Lower Saxony had the lowest share of full-time farmers (63\%). Dairy farming (dairy) is a more important production branch in the North Rhine-Westphalian sample. This is due to the higher share of grassland in the North Rhine-Westphalian rural districts $(12 \%)$. It is obvious that the farms have a relatively high share of arable land (crop). The average valuation index of field (ind) of around 70 points in all federal states reflects a high natural potential yield of the farms.

In regard to most of the parameters, farmers in SaxonyAnhalt claim the more extreme value. For farm structural and economic features this is due to historical reasons (emergence of large cooperatives since the beginning of the 1950s in the former German Democratic Republic). The Saxony-Anhalt farms have, for instance, much higher farm incomes than the farms in Lower Saxony and North Rhine-Westphalia (inc). The same applies to the number of livestock units (lu) and the share of rented utilised agricultural area (rent). Farms in SaxonyAnhalt are on average the largest in the total sample (UAgrass, UAcrop) and have the highest share of arable land integrated in low-input measures (EMcrop). The latter is due to the exclusive implementation of measures which claim a high share of the arable area, such as mulch seeding (79\%), extensification (16\%) and organic agriculture (5\%).

Regarding the socioeconomic data of the farm manager, it is obvious that the share of younger farmers from 20-40 years is in all federal states not very high (age). The differences in the educational level agree with the different structural and economic features of the farms: the farm managers of large competitive cooperative farms in Saxony-Anhalt have a higher educational level than those of smaller family farms in both other federal states (educ).

The farmers' attitudes and personality features show that farmers in North Rhine-Westphalia seem to be much more open towards new and unusual production methods (open). In contrast, the propensity to experiment and willingness to carry a risk (risk) seems to be higher among farmers in Lower Saxony. However, the interest in conserving biodiversity on the farm is highest among farmers in the Saxony-Anhalt sample (int). This is possibly caused by the comparatively high share of farmers in the Saxony-Anhalt sample implementing low-input measures on their farms $(56.6 \%)$. The relation of the farmers with their subsidising institution also seems best in Saxony Anhalt (rel).

\subsection{Determining factors for the implementation of low- input measures on arable land and on grassland}

Table IV shows the influencing factors for the implementation of low-input measures on arable land and on grassland of the total sample.

The $\operatorname{Exp}(b)$ as represented in the table is the ratio of probability (or Odds ratio) for an implementation of low-input 
Table IV. Significant influencing factors for the implementation of low-input measures on arable land and on grassland, calculated by logistic regression (Abbreviations: see Tab. II).

$*: P \leq 0.05 ; * *: P \leq 0.01 ; * * *: P \leq 0.001$.

\begin{tabular}{lll}
\hline & $\begin{array}{l}\text { Measures on arable land }(\mathrm{n}=433) \\
\operatorname{Exp}(\mathrm{B}) ; \text { Nagelkerke } \mathrm{R}^{2}=0.25\end{array}$ & $\begin{array}{l}\text { Measures on grassland }(\mathrm{n}=508) \\
\text { Exp }(\mathrm{B}) ; \text { Nagelkerke } \mathrm{R}^{2}=0.57\end{array}$ \\
\hline Time & $3.325^{* * *}$ & \\
Dairy & $0.442^{* *}$ & $0.931^{* * *}$ \\
Ind & & $1.053^{* * *}$ \\
Grass & & $1.046^{* * *}$ \\
EMcrop & $0.639^{*}$ & $1.827^{*}$ \\
Age & $1.389^{* *}$ & \\
Educ & $0.600^{* * *}$ & \\
Open & $1.325^{* *}$ & $2.292^{* *}$ \\
Risk & & \\
Int & $0.491^{* *}$ & $0.374 *$ \\
NRW & & \\
Nied & $1.332^{*}$ & $4.802^{* *}$ \\
Rel & & $0.004^{* *}$ \\
Contact & $0.122^{*}$ & Chi ${ }^{2}=1.8 ;$ df $=8 ;$ Sig. $=0.99$ \\
Constant & Chi ${ }^{2}=6.0 ;$ df $=8 ;$ Sig. $=0.64$ &
\end{tabular}

measures at constancy of all other variables, if the respective independent variable rises by one unit. It is calculated from the logit coefficients by using the exponential function. An Odds ratio greater than 1 means the respective variable has a positive influence on the adoption of low-input measures, an Odds ratio less than 1 means that the variable has a negative influence. The more different the Odds ratio is from 1, the bigger the influence of the independent variable.

\subsubsection{Farm structural and economic data}

The variables full- or part-time farming (time) and dairy husbandry (dairy) affect only the probability of implementing low-input measures on arable land, but with a rather strong weight. The positive influence of full-time farming is in line with previous studies (Crabtree et al., 1998; Lambert et al., 2007; Wilson and Hart, 2000). The negative influence of dairy farming on the adoption probability is probably caused by a restricted arable fodder or grassland area of these farms, although no parallels could be found in the literature. High average valuation indexes of field (ind) only have a relatively small negative influence on the adoption of measures on grassland, but not on arable land. The influence of the soil quality on the adoption of low-input measures has already been investigated by Dupraz et al. (2003). Furthermore, the odds of adopting measures on grassland rise with an increasing share of grassland in the whole Utilised Agricultural Area (grass). The share of grassland is a good indicator for the farm intensity in the investigated regions. The higher the share of grassland, the more unfavourable the conditions for farming are and the less intensively the farms are managed. Wilson and Hart (2000) emphasise that extensive grassland farms are more likely to partici- pate in low-input measures than intensive livestock or arable farms.

Characteristics of the farm structure have a relatively small weight on the implementation of low-input measures on grassland compared with measures on arable land. The involved farms have relatively small shares of grassland (at an average of $11 \%$ in the total sample, of which $57 \%$ of the farmers had grassland). Hence, grassland measures can be expected to cause no profound modifications of the general farm management. This has been found to inhibit the acceptance of lowinput measures in general (Pannell et al., 2006; Walford, 2002; Wilson and Hart, 2000). For farms geared to arable farming grassland measures will cause, if at all, only a small calculable risk for the whole farm. The implicated risk of a measure is an important impact factor in the decision process of the farmer (Pannell et al., 2006).

\subsubsection{Socioeconomic features of the farm manager}

A high agricultural education level (educ) has a positive influence on the probability of implementing both arable and grassland low-input measures. This impact has been investigated in previous studies as well (Wilson and Hart, 2000; Mathijs, 2003; Walford, 2002; Schmitzberger, et al., 2005; Toma and Mathijs, 2007). The age of the farm manager has often been found to have a negative influence on the adoption probability (Mathijs, 2003; Schmitzberger et al., 2005; Toma and Mathijs, 2007; Walford, 2002). In our study the age had no significant influence on the adoption of measures on grassland, but did on arable land in negative respects. Low-input measures on arable land most often require major modifications of the usual farm management which are more easily accepted by younger farmers (Schmitzberger et al., 2005). 


\subsubsection{Attitudes and personality features of the farm manager}

Openness towards new or unusual production methods (open) has been proved as significant only for measures on arable land. Schmitzberger et al. (2005) also stress the importance of farmers' open-mindedness for the implementation process. The propensity of the farmers to experiment (risk) also had a significant impact on the adoption of measures only on arable land. Farmers' risk-aversion has been investigated as influencing for the adoption process by Pannell et al. (2006). In contrast, an implicit interest of the farmers in conservation of biodiversity (int) exclusively determined the decision to implement low-input measures on grassland. The non-significance of this factor for measures on arable land could be caused by the fact that $45 \%$ of all responding farmers with measures on arable land participated in subsidy programmes for mulch seeding. These innovative procedures indeed require a certain openness and propensity to experiment, but they are predominantly introduced by the farmers for rationalisation and costsaving reasons (e.g. Pannell et al., 2006). This is in agreement with Wilson and Hart (2000), who found arable farmers to have the least conservation-oriented motives for the implementation of low-input measures.

The low implicated risk of grassland measures may be the reason for the non-significance of farmers' openness and propensity to experiment for the adoption of grassland measures. Further, Pannell et al. (2003) describe that the lower the perceived profitability of the measure, the stronger the conservation goals need to be for adoption to occur. Grassland measures in intensively-used regions can hardly be expected to be profitable. Thus, for the implementation of grassland measures, farmers' interest in nature conservation has a significant influence on the decision process.

\subsubsection{The design of low-input measures}

Farmers in North Rhine-Westphalia take significantly less part in low-input measures on arable land (NRW). On the contrary, the fact that a farm is situated in Lower Saxony decreases the probability of adopting measures on grassland (NS). The lower probability of adopting arable low-input measures in North Rhine-Westphalia can be explained by characteristics of the programme design. The agri-environmental programme in North Rhine- Westphalia offers several arable low-input measures, but they are often restricted to certain regions that have a special value for nature conservation. For instance, the generally favoured mulch seeding is subsidised in North RhineWestphalia only in areas that are - based on climate and relief data - classified as especially endangered through erosion. In intensively-used arable regions such as the involved North Rhine-Westphalian rural districts, these premises are often not fulfilled or the measures do not appeal to the local farmers. This can be seen in the comparatively small share of North Rhine-Westphalian farmers with arable low-input measures in the sample who implemented mulch seeding measures (North Rhine-Westphalia 6\%; Saxony-A. 79\%, Lower Saxony 50\%). All other non-ring-fenced arable measures such as low-input field margins (29\%), crop rotation diversification (26\%) and organic agriculture (16\%) supply most of the sample of farmers with arable measures in North Rhine-Westphalia.

Reasons for the slight chance of adopting grassland lowinput measures in the Low Saxon rural districts can also be found in the design of the agri-environmental programme of Lower Saxony. Apart from some exceptions, the offered lowinput measures on grassland are mainly restricted to nature sanctuaries. Further, the extensification of grassland with required minimum and maximum stocking rates has to be implemented on the whole permanent grassland of the farm. The divisibility of a measure into manageable parts is an important prerequisite for its high adoption rate (Pannell et al., 2006; Vanclay, 2004). Non-divisibility could be one possible reason for the lower chance of adoption in the Low Saxon sample.

The adoption of low-input measures on grassland is also dependent on the share of the arable land of a farm integrated in arable low-input measures (EMcrop). Low-input measures on arable land claiming a high share of the arable area are in general measures with comparatively slight restrictions (e.g. mulch seeding). Hence, it can be assumed that in intensive arable regions the access to low input measures having a greater value for nature conservation is facilitated by measures offered with comparatively slight restrictions. Collecting positive experiences with the practice of subsidising and an improved access to information probably facilitate the adoption of other low-input measures. A shift of attitudes towards more conservation-oriented thinking due to the implementation could be another influencing factor (Wilson and Hart, 2000; Whitby, 1994). It has been further investigated that if farmers take part in a subsequent measure, this measure is often similar to the previous one (Wilson and Hart, 2000). We show that subsequently implemented measures can have a quite different character from the starting measures and can spread to other production branches.

\subsubsection{Extension strategies of low-input measures}

Defined contact persons within the subsidising institution (contact) have a very strong influence on the probability of adopting grassland measures. They can guarantee as beneficial investigated face-to-face contact (Schenk et al., 2007; Vanclay, 2004) and facilitate the durable provision of information as another promoting factor (Llewellyn et al., 2007; Toma and Mathijs, 2007). For low-input measures on arable land defined contact persons do not matter, but rather the relation of the farmers with their subsidising institution (rel). Trust in the contact person that originates from a good relationship has been found crucial to enhance adoption rates (Lambert et al., 2007; Pannell et al., 2006; Pretty and Smith, 2004). Presumably in arable farms a good relation, and with this, a raised trust in the subsidising institution are more important for the decision to adopt arable low-input measures because these can often cause deeper changes in the farm management than relatively low-risk grassland measures. In contrast, defined contact persons do not implicitly assure a good relationship, although they may be beneficial for it. Yet they enable the durable provision of a professional advisory service. Caused by a lack 
of experience, farmers in intensively-used arable regions most likely have a greater lack of knowledge in grassland management than their colleagues in regions with traditionally distinct grassland management. These insecurities can be overcome by constant professional advice on management obligations and their possible consequences. Wilson and Hart (2000) describe the influence of different levels of powers and responsibilities of the extension services on the adoption of low-input measures in the European Union. It is obvious that only wellfunded extension services can provide constant professional advice to the farmers.

\section{CONCLUSION}

The differences in the adoption patterns of arable and grassland low-input measures show that the design of agrienvironmental programmes can be much better adapted to intensively-used arable regions. Arable measures with comparatively slight restrictions such as mulch seeding should be offered as starting measures in these regions. They can promote the implementation of probably more valuable nature conservation measures on grassland. Our findings further show that the non-divisibility of measures into manageable parts should be avoided if the adoption of low-input measures in intensive agricultural regions is intended to be increased. Special significance should be attached to the role of the subsidising institution in intensively-used arable regions. We show that a good relationship between farmers and subsidising institutions is getting more important as the offered measures implicate a high risk, whether actual or perceived. The less knowledge the farmers in the responding production branches (like grassland management) have, the more important an available, defined contact person within the subsidising institution is.

Acknowledgements: The authors thank the Deutsche Bundesstiftung Umwelt (DBU) for funding this work through the project network "Lebensraum Börde". We also want to thank the institutions, who helped us distributing the questionnaire and the farmers for taking part in our survey.

\section{REFERENCES}

Andreß H.-J., Hagenaars J.A., Kühnel S. (1997) Analyse von Tabellen und kategorialen Daten - Log-lineare Modelle, latente Klassenanalyse, logistische Regression und GSK-Ansatz, Springer, Berlin, Heidelberg.

Bignal E.M., McCracken D.I. (2000) The nature conservation value of European traditional farming systems, Environ. Rev. 8, 149-171.

Chamberlain D.E., Fuller R.J., Bunce R.G.H., Duckworth J.C., Shrubb M. (2000) Changes in the abundance of farmland birds in relation to the timing of agricultural intensification in England and Wales, J. Appl. Ecol. 37, 771-788.

Crabtree B., Chalmers N., Barron N.J. (1998) Information for Policy Design: modelling participation in a farm woodland incentive scheme, J. Agr. Econ. 49, 306-320.

Davies B.B., Hodge I.D. (2006) Farmers' Preferences for New Environmental Policy Instruments: Determining the Acceptability of Cross Compliance for Biodiversity Benefits, J. Agr. Econ. 57, 393-414.

Dupraz P., Vermersch D., De Frahan B.H., Delvaux L. (2003) The Environmental Supply of Farm Households: A Flexible Willingness to Accept Model, Environ. Resour. Econ. 25, 171-189.
Eggleton P., Vanbergen A.J., Jones D.T., Lambert M.C., Rocket C., Hammond P.M., Beccaloni J., Mariott D., Ross E., Giusti A. (2005) Assemblages of soil macrofauna across a Scottish land-use intensification gradient: influences of habitat quality, heterogeneity and area, J. Appl. Ecol. 42, 1153-1164.

Hosmer D.W., Lemeshow S. (2000) Applied Logistic Regression, 2nd ed., Wiley \& Sons, New York.

Küster H.-J. (1999) Geschichte der Landschaft in Mitteleuropa: von der Eiszeit bis zur Gegenwart. Beck, München.

Lambert D.M., Sullivan P., Claassen R., Foreman L. (2007) Profiles of US farm households adopting conservation-compatible practices, Land Use Policy 24, 72-88.

Llewellyn R.S., Lindner R.K., Pannell D.J., Powles S.B. (2007) Herbicide resistance and the adoption of integrated weed management by Western Australian grain growers, Agr. Econ. 36, 123-130.

Mann S. (2005) Farm Size Growth and Participation in AgriEnvironmental Schemes - A Configural Frequency Analysis of the Swiss Case, J. Agr. Econ. 56, 373-384.

Mathijs E. (2003) Social capital and farmers' willingness to adopt countryside stewardship schemes, Outlook Agr. 32, 13-16.

Milisauskas S., Kruk J. (1989) Neolithic Economy in Central Europe, J. World Prehist. 3, 403-446.

Pannell D.J., Marshall G.R., Barr N., Curtis A., Vanclay F., Wilkinson R. (2006) Understanding and promoting adoption of conservation practices by rural landholders, Aust. J. Exp. Agr. 46, 1407-1424.

Pena de la N.M., Butet A., Delettre Y., Paillat G., Morant P., Le Du L., Burel F. (2003) Response of the small mammal community to changes in Western French agricultural landscapes, Landscape Ecol. 18, 265-278.

Pinto-Correia T., Gustavsson R., Pirnat J. (2006) Bridging the Gap between Centrally Defined Policies and Local Decisions - Towards more Sensitive and Creative Rural Landscape Management, Landscape Ecol. 21, 333-346.

Pretty J., Smith D. (2004) Social capital in biodiversity conservation and management, Conserv. Biol. 18, 631-638.

Schenk A., Hunziker M., Kienast F. (2007) Factors influencing the acceptance of nature conservation measures - A qualitative study in Switzerland, J. Environ. Manage. 83, 66-79.

Schmitzberger I., Wrbka T., Steurer B., Aschenbrenner G., Peterseil J., Zechmeister H.G. (2005) How farming styles influence biodiversity maintenance in Austrian agricultural landscapes, Agr. Ecosyst. Environ. 108, 274-290.

Stoate C., Boatman N.D., Borralho R.J., Rio Carvalho C., de Snoo G.R., Eden P. (2001) Ecological impacts of arable intensification in Europe, J. Environ. Manage. 63, 337-365.

Sutcliffe O.L., Kay Q.O.N. (2000) Changes in the arable Flora of central southern England since the 1960s, Biol. Conserv. 93, 1-8.

Tilman D., Fargione J., Wolff B., D'Antonio C., Dobson A., Howarth R.W., Schindler D., Schlesinger W., Simberloff D., Swackhamer D. (2001) Forecasting agriculturally driven global environmental change, Science 292, 281-284.

Toma L., Mathijs E. (2007) Environmental risk perception, environmental concern and propensity to participate in organic farming programmes, J. Environ. Manage. 83, 145-157.

Vanclay F. (2004) Social principles for agricultural extension to assist in the promotion of natural resource management, Aust. J. Exp. Agr. 44, 213-222.

Walford N. (2002) Agricultural adjustment: adoption of and adaptation to policy reform measures by large-scale commercial farmers, Land Use Policy 19, 243-257.

Whitby M. (1994) What future for ESAs? in: Whitby M. (Ed.), Incentives for Countryside Management: The case of Environmentally Sensitive Areas, CAB International, Wallingford, pp. 252-273.

Wilson G.A., Hart K. (2000) Financial imperative or conservation concern? EU farmers' motivations for participation in voluntary agrienvironmental schemes, Environ. Planning A 32, 2161-2185. 